\title{
REVIEW OF LABOR ARBITRATION AWARDS ON JURISDICTIONAL GROUNDS
}

\author{
Eugene F. Scoles* \\ INTRODUCTION
}

1

THE INCREASED USE of arbitration as a means of settling labor disputes has caused an increase in the problems concerning judicial review of the labor arbitration award. While 95 per cent or more of the awards made annually probably never get into court, ${ }^{1}$ a few instances of judicial review raise a question as to the function of the court reviewing an award on jurisdictional grounds. A limited area of review may be unavoidable and perhaps desirable in isolated instances. Arbitration is a creature of the parties; they may choose their own judge, procedure, and criteria for decision. In view of this and the agreement of the parties to be bound by the decision of the impartial arbitrator, much judicial review is undesirable.

Judicial review of an award may arise in an action on the contract as interpreted by the award or in a procedure to enforce the award. In either case, the court may of necessity review the action of the arbitrator as an incident of the enforcement procedure. ${ }^{2}$ This indirect review

* Associate Professor of Law, University of Florida College of Law.

× Gregory and Orlikoff, The Enforcement of Labor Arbitration Agreements, $x 7$ Univ. Chi. L. Rev. 233, 235 (I950). See Kellor, Arbitration in Action r39 n. 2 (I94I): "In the arbitrations held under the Rules of Procedure of the American Arbitration Association, approximately 6 per cent of the commercial case awards have been filed with the courts for entry as judgments. In its industrial arbitration between management and employees, an even higher percentage of observance by both management and unions prevails. On the other hand, it is true in states having laws that make legal enforcement of awards difficult, arbitration is little used, indicating a lack of confidence in the remedy itself where there is no ultimate legal compulsion." In Updegraff and McCoy, Arbitration of Labor Disputes I25 (1946), it is observed that labor arbitration awards are "practically never" converted to judgments. "[F]irst, because the parties are anxious to avoid the courts, and second, because labor disputes are usually of such a nature that no benefit would accrue from the securing of a judgment." Freiden and Ulman, Arbitration and the National War Labor Board, 58 Harv. L. Rev. 309, 316 n. 25 (1945), set forth some statistics illustrating how seldom labor arbitration awards find their way into courts.

2 For a brief summary of the enforcement of awards at common law on a contract theory, see 6 Williston, Contracts $\$ \S \times 9$ rg-1930 (rev. ed. 1937 ). A review of statutory procedure is found in Ziskind, Labor Arbitration under State Statutes (U.S. Dept. of Labor, I943), where it is pointed out that "there are no less than Ir6 separate methods of labor arbitration authorized by State statutes." See Braun, Settlement of Industrial Disputes 227 et seq. (1944). Federal arbitration systems are also discussed in Braun, op. cit. supra at I45. The participation of government on all levels in the settlement of industrial disputes is considered in Kaltenborn, Governmental Adjustment of Labor Disputes (I943). 
usually comes as a part of the decision as to whether a collateral attack on the award will be allowed. As contrasted with this, direct review may be had when the court directly inquires into the validity of the award. Matters arising on direct review will be discussed here.

In theory, the basis for judicial review of an arbitrator's award is very narrowly restricted. The New York court of appeals has stated it in this manner: "The award of an arbitrator cannot be set aside for mere errors of judgment, either as to the law or as to the facts. If he keeps within his jurisdiction and is not guilty of fraud, corruption or other misconduct affecting his award, it is unassailable, operates as a final and conclusive judgment, and, however disappointing it may be the parties must abide by it."

In the absence of misconduct on the part of the arbitrator, this would seem to limit the court to a review on jurisdictional grounds. ${ }^{4}$ The rationale of review on jurisdictional grounds is that arbitration is based upon the voluntary consent of the parties to be bound by the decision of the impartial arbiter. The enforcibility of an award rests entirely upon this consent as it is expressed in the collective agreement, and in so far as it is effective, moral suasion. If the arbitrator by his award goes beyond the matter submitted to the arbitration process in the agreement, his award is unenforcible because the necessary element of consent is lacking. This question of the scope of the submission agreement is the major, actual or alleged basis of judicial review, and most cases fall within this category.

The submission agreement is usually found in the collective bargaining agreement between the employer and the union representing his employees. Many such contracts have a provision to the effect that "[a]11 such disputes, misunderstandings and grievances... arising out of or in any manner connected with this Agreement which the parties are unable to adjust or settle among themselves (except such as are not subject to arbitration hereunder) shall be submitted to arbitration...."."

Nearly all grievance procedures limit arbitration to "disputes arising under this contract" or define grievances as "disputes about the inter-

3 Matter of Wilkins, I69 N.Y. 494,62 N.E. 575 (1902), quoted with approval in Motor Haulage Co. v. Int'l Bro. Teamsters, Local 807, 272 App. Div. 383 , 7 I N.Y.S. 2d 352 (r947).

1 See In re General Dry Cleaners, 75 N.Y.S. 2d 615, 6I8 (1947), for a detailed list of grounds for vacating awards by one participating in the arbitration proceedings.

5 Art. VII B(2) of the agreement between Brooklyn Union Gas Co. and Local ror, Utility Division, Transport Workers Union of America, CrO, dated February 26, 1947- 5 C.C.H. Lab. L. Rep. II 53,120 (1950). 
pretation or application ... and about alleged violations of the Agreement." Such restrictions limit the issues which may be decided by the arbitrator with the result that arbitrability of the issue is the major question of jurisdiction.

The clauses defining the arbitrable issue are usually followed by a provision to the effect that the arbitrator "shall have no power to add to or subtract from or modify any of the terms of this Agreement." This places a second jurisdictional restriction on the arbitrator as to the nature of the award to be made on an admittedly arbitrable issue. These two problems of what the arbitrator has to decide and how he can decide it overlap considerably and often are inseparable. They will be considered here however, as separable aspects of the jurisdictional basis of review.

\section{Finatity of Award Construing Jurisdictional Limitations on SUbject Matter}

Even though jurisdiction appears to be the first point of inquiry, there exists the preliminary question of whether the court is free to consider the issue of arbitrability. Often one of the parties objects to the jurisdiction of the arbitrator in the arbitration proceedings and the issue is passed upon by the arbitrator. May the arbitrator in this way decide finally his own jurisdiction by means of a bootstrap doctrine? This issue of arbitrability usually arises in situations in which the parties are going to arbitration under the grievance procedure of a collective bargaining agreement whereby they have agreed to submit future disputes to arbitration. It may also arise under an express submission of an existing dispute after proceedings have begun, but because the parties in this latter instance usually draft the submission to cover completely the existing dispute, it normally does not.

Goldstein v. International Ladies Garment Workers' Union ${ }^{8}$ is illustrative. There a member of an association discontinued its plant in Philadelphia and continued to operate an existing plant at another city. The union, which had an agreement with the association, charged that the company had violated a clause prohibiting removal of a plant from

${ }^{6}$ Art. VI of the Agreement between Lever Brothers Co. and Local 336, United Gas, Coke, and Chemical Workers of America, CIO, dated August 29, I947. 5 C.C.H. Lab. L. Rep. I 53,170 (1950).

7 Section 46 of the agreement between General Motors Corp. and UAW-CIO dated May 29, I948. 5 C.C.H. Lab. L. Rep. If 53, IOI (1950). Section I8(b) of the agreement between Ford Motor Co. and UAW-CIO dated Sept. 29, I947- 5 C.C.H. Lab. L. Rep. If 53,I60 (I950).

${ }^{8} 328$ Pa. 385, I96 Atl. 43 (I938). 
Philadelphia, and went to arbitration under the contract's grievance procedure. The company appeared before the arbitrator and denied his jurisdiction on the grounds that the contract with the association did not apply to it because it had a single company contract with the union which it alleged superseded the association contract. The arbitrator in his award found that (I) he had jurisdiction because the association contract was binding on the company; (2) the company had moved its plant in violation of the association contract. He ordered the company to return to Philadelphia and employ its former employees. On proceedings for confirmation of the award, the lower court held that the contract question was a question of fact upon which the arbitrator's finding was conclusive. The company appealed and the supreme court of Pennsylvania reversed, holding that the questions in this case relating to the submission agreement were jurisdictional and not subject to final determination by the arbitrator. The court reasoned that as questions of law, they were always subject to court review, and further, that due process of law required such a review of the jurisdiction of the arbitrator. ${ }^{9}$ It should be noted that the company objected to the submission throughout the proceedings and did not waive any of its rights.

In a similar California case ${ }^{10}$ the company argued before the permanent referee that a question of adding a maintenance of membership clause to the collective bargaining agreement was not within the arbitration clause of that contract. The arbitration clause provided that the arbitrator should not "have jurisdiction to arbitrate provisions of a new agreement or to arbitrate away, in whole or in part, any provision of

\footnotetext{
9 The court referred to the issue of the arbitrator's jurisdiction and stated that the "appellants not only had a right under the statute but even a constitutional right to have that issue determined by a judicial tribunal." Goldstein v. Int'l Ladies Garment Workers' Union, note 8 supra, at 392. The court approved the result of the leading case of Finsilver, Still \& Moss, Inc. v. Goldberg, Maas \& Co., Inc., 253 N.Y. 382, 389 I7I N.E. 579, 58I (r930), in which Cardozo, C. J. stated: "Arbitration presupposes the existence of a contract to arbitrate. If a party to a controversy denies the existence of the contract and with it the jurisdiction of the irregular tribunal, the regular courts of justice must be open to him at some stage for the determination of the issue. The right to such a determination, either at the beginning or at the end of the arbitration or in resistance to an attempted enforcement of the award, is assured by the Constitution as part of its assurance of due process of law." The same holding appeared in Schafran \& Finkel, Inc. v. Lowenstein \& Sons, Inc., 280 N.Y. I64, I9 N.E. 2 d I005 (I939). If such a judicial determination is not permitted, the result is compulsory arbitration without even the aid of a statute which would seem to be invalid under Chas. Wolff Packing Co. v. Court of Industrial Relations, 262 U.S. 522 (r923), and Dorchy v. Kansas, 264 U.S. 286 (rg24). See also Simpson, Constitutional Limitations on Compulsory Industrial Arbitration, 38 Harv. L. Rev. 753 (r925); Braun, Settlement of Industrial Disputes I35 (I944).

${ }^{10}$ Consolidated Vultee Aircraft Corp. v. United Automobile Workers, I6o P. 2d II3 (Calif. App., r945). A subsequent appeal of this case was dismissed as moot when the parties had replaced the old agreement with a new contract. 27 Cal. 2d 859, I67 P. $2 \mathrm{~d} 725$ (I946).
} 
this agreement." The arbitrator's award granted maintenance of membership, and the company raised the scope of submission issue on proceedings to confirm.

The court held that it could review the scope of submission under the contract and found that the arbitrator had exceeded the scope of his authority. The court stated: "It was the duty of the court to determine from the agreement the extent of the referee's powers and to annul any or all of the provisions of the award as to matters which had not been submitted to him for decision."11 The same view was stated by a federal district court when the position was taken that " $[\mathrm{t}] \mathrm{he}$ terms of the submission are the relevant portions of the contract, and those portions are appropriate for construction by a court of competent jurisdiction, just as are all other provisions of the contract."12

Most contracts limit arbitration to "disputes arising under this contract," or contain similar provisions. ${ }^{13}$ Whenever a motion is made to confirm or vacate an arbitrator's award under such a contract, the court is called upon to enforce a contract to arbitrate certain limited controversies. The court cannot avoid the duty of determining whether the particular dispute is one which the parties agreed to arbitrate. ${ }^{14}$

Much of the language in the cases indicates that many courts feel that the question of interpretation of the arbitration clause cannot be submitted to the arbitrator. However, the basic premise of arbitration-consent to be bound by the award-places no limit on the issues which may be submitted to the arbitration process. From this it seems there is no reason why the parties to an arbitration agreement cannot submit to the arbitrator all disputes concerning the meaning and scope of the arbitration clause as well as the meaning of a seniority clause or any other provision of the contract. ${ }^{15}$ Where such a submission has

Ir Ibid., at $x$ I8.

${ }^{2}$ Oil Workers Int'l Union v. Texoma Nat. Gas Co., 58 F. Supp. I32 (Tex., I943), aff'd I46 F. 2d 62 (C.A. 5th, I945), cert. den. 324 U.S. 872 (I944). See also Solomon v. Forty-Second Street Fotoshop, 72 N.Y.S. 2d 639 (1947).

${ }^{13}$ Note 6 supra.

${ }^{14}$ Matter of Simons, 6 C.C.H. Lab. L. Rep. I 65,402 (S.Ct. N.Y., I949).

${ }^{25}$ This is not inconsistent with the following statement from Silva v. Mercier, $33 \mathrm{Cal}$. 2d 704, 709, 204 P. 2d 609, 613 (I949): "It has been held that the issue of whether a contract containing an arbitration clause exists, or is still in effect, is not within the purview of the arbitration clause for the reason that if there is no contract there is no provision for arbitration." Compare General Electric Co. v. United Electrical Workers, CIO, 6 C.C.H. Lab. L. Rep. I 65,546 (S. Ct. N.Y., I949); Matter of Dumas, I6 C.C.H. Lab. Cas. If 64,944 (S. Ct. N.Y., I949). 
been made, the arbitrator's interpretation of the scope of the submission should be no less final than his ruling on other questions or clauses. Any contrary position overlooks the underlying theory of arbitration: consent to be bound by the award. ${ }^{16}$ This question of arbitrability is especially important in labor cases not only because the arbitration clauses are often written in broad terms which seem to give the arbitrator final authority ${ }^{17}$ but also because arbitrators in actual practice are expected to-and do repeatedly-pass on the scope of their jurisdiction. ${ }^{18}$

The reasoning of the courts in the Goldstein and Consolidated cases is probably technically consistent with the proposition that, should the parties so desire, they may submit the question of arbitrability, as any other question of contract interpretation, to the arbitrator and be bound by his decision. The problem of the existence of an agreement to submit the question of arbitrability arose more clearly in Belding Heminway Co. v. Wholesale Workers' Union. ${ }^{10}$ In this case a member of an association of warehouse owners operating in the "Uptown Area" of New York City opened a new warehouse in New Jersey and curtailed operations in New York. The union sought arbitration of a dispute arising out of the employment of nonunion men at the new warehouse and alleged that this violated the closed-shop provisions of the "Uptown Area" association contract which purported to cover any dispute, grievance, or complaint "between the parties." The company refused to arbitrate and sought a court order staying arbitration and directing a trial on the issue of the existence of a contract to arbitrate this matter. The supreme court denied the company's motion and the appellate division affirmed. ${ }^{20}$ The court of appeals reversed, and in a per curiam opinion stated: "Whether the appellant was bound to employ at its New Jersey plant members of the respondent union was a debatable question

${ }^{16}$ Belding Heminway Co. v. Wholesale Workers' Union, 295 N.Y. 54I, 68 N.E. 2d 68I (1946); Matter of Publishers Assoc., 6 C.C.H. Lab. L. Rep. $\$ 65,47$ I (S. Ct. N.Y., 1949).

${ }_{17}$ See General Motors Agreement, note 7 supra. The General Motors Contract apparently contemplates the arbitrator's decision as to the arbitrability of any matter in the same section which stated in part, "Any case appealed to the Umpire on which he has no power to rule shall be referred back to the parties without decision."

${ }^{8}$ Armour \& Co. and United Packinghouse Workers of America Arbitration No. 2-G (r947); Bethlehem Steel Co. and United Steelworkers of America, 5 B.N.A. Lab. Arb. 684 (I946); Ford Motor Co. and United Automobile Workers, Opinion A-r5o (r944).

×9 295 N.Y. 54r, 68 N.E. 2d 68I (1946).

${ }^{20} 270$ App. Div. 879, 6r N.Y.S. 2d 302 (1946). 
which called for a decision as to the scope of the collective bargaining agreement between the parties. This question, we think, was for the court, not for the arbitrators." 21

The problem of a decision on arbitrability by the arbitrator also arose in Rogers Diesel and Aircraft Corp. v. Local $1259 .^{22}$ There the grievance procedure covered "any dispute about working conditions" and any "dispute about the interpretation and application of particular clauses of this agreement and about alleged violations of the agreement...." The company disciplined employees for alleged violation of company rules and the union moved for arbitration. The company sought a court order staying arbitration. The court refused, ruling that the dispute "whether or not the particular issue of suspension is arbitrable involves an interpretation and application of particular clauses, which latter question is arbitrable."

Many union contracts in effect today have very broad provisions for grievance adjustments terminating in arbitration. These clauses form an integrated part of the contract and, in the view of many, the most important part. The inclusion of grievance procedure clauses covering "any dispute, claim, question or difference arising out of or relating to this agreement" would appear to disclose an intent to forego court action regarding all problems concerning that agreement. ${ }^{23}$ At least the courts should consider the parties' intention as it is reflected in such broad clauses. Heretofore the emphasis has been on the merits of the dispute: that is, whether the acts complained of came within the scope of the agreement. To force a company or a union to abide by an award when it has not consented to arbitration would appear to be a violation

${ }^{22} 295$ N.Y. 54r; 68 N.E. 2d 68I (x946). Application of Graphite Metallizing Corp., $27 \mathrm{I}$ App. Div. 839,66 N.Y.S. $2 d 53$ (I946), was a proceeding to stay arbitration of a dispute concerning a person leaving the company's employ six months before the collective bargaining agreement became effective. The court followed the Belding Heminway case and stated, "The question of law thus presented as to the scope of the collective bargaining agreement was for the court, and not for the arbitrator to decide." See also Matter of Publishers Assoc., 6 C.C.H. Lab. L. Rep. I 65,47 (S. Ct. N.Y., I949).

${ }^{22}$ I5 L.R.R.M. 848 (S. Ct. N.Y., r945).

${ }^{23}$ This was the clause in the contract between the employer and the union in Oppenheim, Collins \& Co. v. Display Union, 73 N.Y.S. 2 d 673, 674 (I947), where the contract also vested the employer with "sole discretion" as to the necessity of dismissals due to business exigencies and the court held the matter was not arbitrable and could not be submitted to arbitration. This holding would seem to preclude on a basis of scope of submission, any determination that the dismissals were or were not caused by business exigencies. At the same time the court also held the propriety of employment of nonunion members under a closed shop contract was arbitrable. Compare Stein v. Local 680 of Milk Drivers \& Dairy Employees, I4I N.J. Eq. 226, $5^{6} \mathrm{~A}$. 2d $7 \mathrm{I}_{5}$ ( 1948 ), where the court considered the arbitrator to have no right to determine the question of rescission of the union contract. 
of due process and clearly undesirable. However, there appears no reason why the parties may not submit the issue of arbitrability to arbitration. The question for the court on the scope of submission should therefore include an inquiry to determine whether the parties have by any act agreed to be bound by the arbitrator's decision on the question of arbitrability.

Finality of Award Construing Limitations on Nature of Award

The clauses defining the disputes subject to arbitration usually include or are followed by a provision that the arbitrator shall make no ruling in "conflict with the provisions of the agreement" nor "add to or modify" the agreement. ${ }^{24}$ This type of clause suggests a problem distinct from, although similar to that of the finality of an award on arbitrability. Does such a restriction impose a limitation on the arbitrator's power which the parties intend the courts to interpret and enforce? Or does it lay down a rule of construction for the arbitrator to follow and as to which he has the final word? The General Motors clause indicates that the parties contemplated a decision by the umpire on this question. ${ }^{25}$ Such a decision apparently would be valid. When the contract provides that "all disputes" are subject to arbitration but that the award should not "conflict" with the terms of the agreement, it would seem that this same result could well be contemplated by the parties. Such a clause was found in Screen Cartoonists Guild Local 852 v. Dis$n e y^{26}$ in which the court held the arbitrator had exceeded his authority even though he appeared to have made a good faith attempt, supported by evidence, to interpret the provisions of the contract consistently with the intent of the parties.

That this is a genuine problem is shown by Western Union v. Communications Assn. ${ }^{27}$ In that case the contract contained the following submission provision in the grievance procedure:

In the event that an agreement cannot be reached between the Union and the Company with respect to the application or interpretation of this contract . . . it is agreed that such matters will be submitted ... to Max Meyer, as impartial arbitrator.... The arbitrator shall not have authority to alter or modify any of the express provisions of the contract. ...

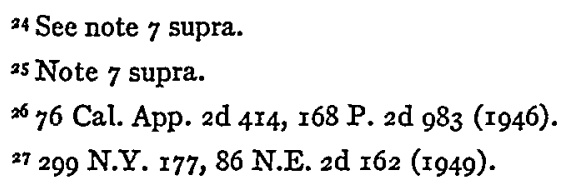


The arbitrator interpreted the "no strikes or other stoppages of work" clause to permit employees to refuse to handle "hot traffic" messages from struck companies by reading into the clause the practice and custom prevalent in the telegraph industry. The New York court of appeals vacated the award because:

By that conclusion, as we view it, the arbitrator-entering a field of decision from which the parties had expressly excluded him-modified an express provision of the contract by which the union had agreed that "there shall be ... no stoppages of work during the life of this contract." As the language employed leaves no doubt as to its meaning "there is no occasion to resort to other means of interpretation."28

The dissenting judges considered it "a pure question of interpreta- , tion and application, and the very kind of question which the parties themselves had agreed should be decided by the arbitrator alone."

Whether or not this is a jurisdictional matter is debatable. Such a clause should be given a rather limited scope in order to be construed consistently with one submitting "any" or "all" disputes to arbitration. Having in mind the usual desire of parties to labor disputes to stay out of the courts, the courts should weigh the possible intention to consider this as a rule of construction for the arbitrator. Under the clauses in the General Motors, Disney and Western Union contracts it seems a reasonable interpretation of the submission that the parties anticipated a binding award on this point. This is within the principle that the parties may submit questions of arbitrability if they so desire.

\section{JURISDICTIONAL REVIEW OF THE MERITS}

The preceding discussion presumes the court has the right if not the duty to review the scope of submission or jurisdiction of the arbitrator. When the arbitrator proceeds beyond the issue of the submission, the parties are not only improperly bound without their consent, but the arbitrator has no reasonable basis upon which to make a just award. ${ }^{28}$

\footnotetext{
${ }^{28} \mathrm{Ibid}$., at 184 and $x 66$. The court also gave the additional grounds that the contract as interpreted permitted violation of a penal statute regulating the service of public utilities. It seems apparent however, that the court reviewed the award as it would a lower court decision when it stated: "We know of no case where a court, in construing ... language as clear as is the clause here in controversy, has found it necessary to employ extrinsic means to ascertain a party's obligation thereunder." Ibid., at I 85 and $r 66$. This discussion perhaps raises the broad question of whether evidentiary matters come within the scope of arbitration issue. It is believed that an exploration of that issue would unduly extend this article. Therefore, the question of whether an arbitrator is limited to the evidence submitted by the parties, or may rely upon such extrinsic matters as his independent knowledge of the circumstance, custom and usage within the industry, or decisions of other arbitrators, is not included within the scope of this paper. It is believed that this is more appropriately treated as a hearing or post-hearing matter.
}

${ }^{29}$ See Publishers Ass'n v. N.Y. Typo. Union, I68 N.Y. Misc. 267, s N.Y.S. 2d 847 (1938). 
The interest of the parties and of justice therefore require that the court act in such cases. Under any restrictive submission clause, however, the courts are in danger of intruding themselves into the merits under the guise of determining whether the arbitrator has jurisdiction. With the growing acceptance of the restrictive clauses noted above, this is an increasing danger. In such situations, the reviewing court occasionally appears to go beyond the actual problems of submission by means of a purported review of the arbitrator's jurisdiction. In the Disney case, ${ }^{30}$ the company and the union included a clause in their contract stating that the regular hours of work would be "[e]ight hours per day, forty hours per week, five days per week, Monday through Friday inclusive." The contract also included premium pay clauses required by Executive Order 9240 providing premium pay for the sixth and seventh days of a work week. The contract further provided for paid holidays when they fell within the work week. Two holidays fell on Saturday and the company refused to pay therefor and the parties went to arbitration under a clause covering "all complaints" but with a provision binding the arbitrator to the terms of the contract. ${ }^{31}$ The arbitrator noted that the term "work week" was used only in the holiday clause and the Executive Order 9240 clause. Executive Order 9240 had been interpreted to mean a work week of seven consecutive days. The same definition had been adopted under the Fair Labor Standards Act and was generally accepted by industry. In line with this, the arbitrator concluded that "the form of clause Fifth [Executive Order 9240] indicates a concept of the work-week as seven days, some of which are straight-time days and others overtime days.... Since the term 'work-week' clearly means seven days where it is used earlier in the contract, it is reasonable to interpret it as meaning the same thing in clause Eleventh [holiday clause]." On proceedings to confirm, the trial court granted the company's motion to vacate and on appeal the trial court was affirmed. The court of appeals of California found there was "no doubt that

${ }^{30}$ Screen Cartoonists Guild Local 852 v. Disney, 74 Cal. App. 2d 414, r68 P. 2 d 983 (I946).

${ }_{35}$ The pertinent parts of the grievance procedure provided: " 4 . All complaints, grievances, controversies, disputes, questions of interpretation of this agreement and all other differences between the parties hereto, shall be heard and determined by the Impartial Chairman (arbiter), if the same cannot in the first instance be otherwise disposed of under provisions hereof between the parties hereto. Said Impartial Chairman shall have power to make and enter any order, ruling or decree which in its judgment appears to be just and reasonable, having due regard for justice and equity in each case; such ruling or decree, however, shall not be in conflict with the express provisions of this agreement. 5 . . . Each case brought to the Impartial Chairman shall be considered on its own merits, and this agreement shall constitute the basis upon which such decision sizall be rendered." (Italics added.) 
clause fifth ... fixed a regularly scheduled work week of five days.... Otherwise, if a work week of seven days had been contemplated, all holidays would fall within such work week, and clause eleventh would cease to have any meaning." After thus effectively reviewing the merits, the court concluded:

From the foregoing, it appears that in construing the work week to include Saturday, the arbiter's ruling was in direct conflict with the express terms of the bargaining contract, and thus exceeded the powers conferred upon him under clause thirteenth, heretofore quoted. ${ }^{32}$

The company and the union in I.A.M. v. Cutler-Hammer, Inc. ${ }^{33}$ agreed to meet "early in July I946 to discuss payment of a bonus for the-first six months of I946." In July I946, the parties met and the company agreed to discuss, but not to pay, the bonus. The union urged that payment had been agreed upon and the discussion referred to in the contract was to concern the amount to be paid. On disagreement the union moved to compel arbitration under the grievance procedure providing for arbitration of disputes as to the "meaning, performance, nonperformance or application" of the contract provisions. The company moved to stay arbitration. The trial court ordered arbitration and on appeal the appellate division reversed and stated in its per curiam opinion:

The clause of the agreement that "the Company agrees to meet with the Union early in July I 946 to discuss payment of a bonus for the first six months of 1946 " can only mean what it says, that the parties will discuss the subject. While the contract provides for abitration of disputes as to the "meaning, performance, nonperformance or application" of its provisions, the mere assertion by a party of a meaning of a provision which is clearly contrary to the plain meaning of the words cannot make an arbitrable issue. It is for the Court to determine whether the contract contains a provision for arbitration of the dispute tendered, and in the exercise of that jurisdiction the Court must determine whether there is such a dispute. If the meaning of the provision of the contract sought to be arbitrated is beyond dispute, there cannot be anything to arbitrate and the contract cannot be said to provide for arbitration. ${ }^{34}$

On appeal the Court of Appeals of New York affirmed without opinion. Judge Fuld, dissenting, stated:

I have difficulty in concluding, as respondent urges, that reasonable men cannot differ as to the meaning of the provision in question. While I see that as a possible construction, I do not consider it the only one. It may well be argued, and in good faith, that in the light of surrounding circumstances and of experience in the in-

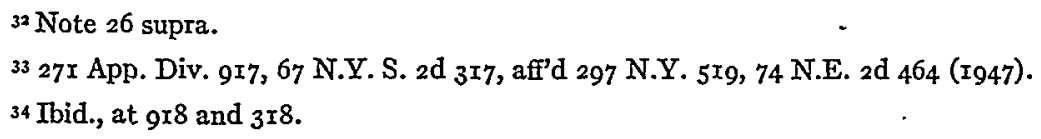


dustry and, indeed, in this very business, respondent company agreed that a bonus would be paid-at least where the company's business warranted-and that it would discuss with the employees the amount of payment, i.e., "payment of a bonus."

If there is a possibility of such a construction, the court should not remove the controversy from the sphere of arbitration, particularly when the applicable arbitration clause- "If any dispute shall arise ... as to meaning, performance, nonperformance or application of the provisions of this agreement"-is so broad.35

Both the Disney case and the Cutler-Hammer case appear to be instances in which the court effectively reviewed the merits of the findings of the arbitrator under the guise of a review as to the scope of the very broad submission clauses. One of the chief advantages of arbitration is to secure the adjudication of disputes by persons trained in the field and familiar with the manner in which the industry operates. To permit review of the merits by a court in such cases is to lose this advantage. However, assuming that on the merits the union's contentions in both cases were wrong, still the parties had agreed to arbitration under broad clauses and had in effect agreed to be bound by the decision resulting from arbitration. The value of a court review of the merits even if the award is concededly wrong is seriously questioned. The cases seem to illustrate the undesirable manner in which the courts, by interjecting themselves into the arbitration of labor disputes, may depress the faith of the parties in arbitration. It is upon this faith that the bulk of good labor relations depends.

The danger that the courts will review the merits on jurisdictional grounds constantly recurs because jurisdictional grounds are advanced in nearly every case as a basis for review of an award which is unsatisfactory to one of the parties. Then too, in many cases it is difficult to draw the line between the scope of submission review that is a necessary protection for the parties and the less desirable practice of using it as a means of reviewing the merits of the controversy. It is submitted, however, that the courts can aid all parties to labor disputes by giving full effect to the submission agreement contemplated by the parties and by avoiding a review of the merits of the award.

\section{Time Limitations}

The prior cases discussed involved the question of whether the factual basis of the case came within the submission clause. The scope of submission question comes up in a somewhat different form in the time limitation cases. The time limitation appears in two situations: one,

${ }^{35} 297$ N.Y. 5 Y9, 74 N.E. $2 \mathrm{~d} 464$ (1947). 
when arbitrators are to make their award within a specific period of time; the other, when the various steps in the grievance procedure are subject to specified periods of limitation. The first is' a part of the traditional arbitration proceeding while the second is becoming a more important feature of the four-or five-step grievance procedure common to present day collective bargaining agreements. In Hegeberg v. New England Fish Co., the first type of problem arose in familiar circumstances. ${ }^{38}$ The union and the canners were negotiating prices just before the opening of the salmon season. Unable to agree and pressed by the coming salmon run, the parties agreed on minimum prices and agreed to arbitrate the difference with a provision that the award was to be filed with the Federal Conciliator by August 25, I938. Meanwhile work went on for the whole season. The board of arbitration set the wage and price scales for some one hundred canneries on the Alaskan coast. They reached unanimous agreement on this multitude of rates on August 24, informed the conciliator orally on August 25, and filed a formal written award on August 26. In an action by the employees for wages based on the award, the companies urged that the filing of the award did not comply with the requirements of submission. The supreme court of Washington, however, enforced the award. ${ }^{37}$

The same problem of an award after expiration of a time limit in the submission arose in a case in which a controversy regarding modification of a contract between a union and a railroad was submitted to a board of arbitrators under the Railway Labor Act. ${ }^{38}$ The stipulation provided for the filing of the award within fifteen days from the beginning of hearings. Immediately after the hearing an informal vote was taken at which the union appointee and the Federal Mediation Board appointee voted for a clause paying overtime after eight hours of work per day. The public member wrote up a draft award and included a

${ }^{36} 7$ Wash. 2d 509, IIO P. $2 \mathrm{~d}$ I82 (I94I).

37 Replying to the defendant's contention, the court said, "A sound and well recognized public policy strongly supports arbitration of disputes between employers and employees. Apparently all parties relied upon the anticipated appraisement in entire good faith.... The trifling delay in the filing of the award could make no possible difference to anyone. The essence of the matter was to settle what was an apparently bitter dispute between employers and employees, and to enable the fishing to proceed, thereby avoiding great loss to all parties concerned. . . We are convinced ... that it should not be held that the slight delay in filing the award should render the award void." 7 Wash. $2 \mathrm{~d} 509,5^{\text {I } 2}$ et seq., IIO P. 2d I82, I87 et seq. (r94I).

${ }^{38}$ Brotherhood of Ry. and S.S. Clerks v. Norfolk So. Ry. Co., I43 F. 2 d IoI5' (C..A. $4^{\text {th, }}$ I944). 
clause to the effect that if the award forced a curtailment of service to the public, it should be abrogated by mutual agreement. The labor member refused to sign it and the resulting difference caused such a delay that the award was not made or filed until ninety days after the beginning of the hearing. Meanwhile, fifty-five days after beginning of the hearings, the company had filed a suit to impeach and vacate any award that might be made. The district court impeached the award and the union appealed. The Court of Appeals for the Fourth Circuit affirmed. The court pointed out that the Railway Labor Act required "prompt and orderly settlement" of disputes and that the parties themselves set a time limit. The Railway Labor Act permits impeachment of an award to be had for lack of substantial conformity to the Act or submission but not "for trivial irregularity or clerical error, going only to form and not to substance." 30 Time was of the essence in arbitration at common law and the statute had made no change in that regard. Further the deviation from the submission was substantial so that the board was without authority and no award could properly be made. ${ }^{40}$

Both of these cases recognize a principle favorable to arbitration and consistent with the scheme of arbitration free from unnecessary formality and technicality. The slight delay occasionally incident to the filing of an award should not be permitted to destroy its effect. On the other hand, the need for speed and compliance with the reasonable limitations of the submission require prudent review of substantial delays and breaches of the submission agreement. A prejudicial delay should not be tolerated and yet an insignificant one should not destroy the time and effort invested in the settlement of a dispute.

The second type of time restriction problem arises in many present day collective bargaining agreements which provide for a time limitation period at each step of the grievance procedure. By this device, the last answer of the party against whom the grievance or complaint is made, normally the company, becomes the final disposition of the matter if it is not carried to the next step of the grievance procedure within a stated number of days. At the lower levels of management this period is usually rather short, lengthening as the matter is considered by top management and union officials with usually the longest period just

\footnotetext{
${ }^{39} 45$ Stat. 585 (r926), 45 U.S.C.A. I59 (r943).

10 Compare Pratt, Read \& Co. v. United Furniture Workers, 70 A. 2d I20 (Conn., I949). On this problem generally see Annotation, I54 A.L.R. 1392 (1944).
} 
before arbitration. In Atlantic Coast Line R. Co. v. Pope, the court held that such a contract limitation was effective to bar further action after a failure to appeal an adverse decision on a complaint. An award made thereafter on the same claim was invalid. This decision seems proper and offers considerable protection against stale claims. After submission the parties have made earnest effort to settle the dispute and have expended considerable time and expense to protect this investment; some leniency in regard to limitation clauses should therefore be tolerated. However, many of these factors are not present in the steps of the grievance procedure below arbitration. The procedure there is part and parcel of the bargaining process between the employer and his employees or their representatives. It is a recognized benefit in these relations that complaints and grievances be settled quickly and not left to smolder and cause discontent. Time limitations in the pre-arbitration stage promote healthy labor relations by providing speedy disposition of grievances, and adherence to them -should be encouraged, more so than after the matter has left the hands of the principals and has gone into the hands of the third-party arbiter.

Even though a time limitation in the grievance procedure seems beneficial to prevent stale claims, there remains the question whether this limitation should be considered jurisdictional or simply a rule of limitation to be applied by the arbitrator. In the instance of whether Sundays or holidays are counted as part of the limitation period, rather difficult complications would result if the award was vacated because the arbitrator and the court differed as to whether such a day should be counted. Further, since this is a matter of agreement between the parties, this limitation may be waived. Being subject to waiver, it does not seem jurisdictional in the normal sense of that term. Still it appears to go to arbitrability and should be considered along with other arbi-

$4^{\mathrm{x}} \times \mathrm{x}_{9}$ F. 2 d 39 (C. A. $4^{\text {th }, ~ I 94 x) . ~ A n ~ i n t e r e s t i n g ~ p r o b l e m ~ i n c i d e n t ~ t o ~ t h i s ~ h o l d i n g ~ i s ~ o n e ~}$ which was of greater importance prior to the Portal to Portal Act of $x 947,6 \pi$ Stat. 84 (I947), 29 U.S. C.A. \& 25 I (Supp. 1949). The federal courts had taken the position that an agreement to arbitrate "any difficulty or disagreement . . . in any way growing out of the relation of employers and employee" precluded an action at law for overtime under the Fair Labor Standards Act. Donahue v. Susquehanna Colliers Co., r38 F. 2d 3 (C.A. 3 d, r943); Watkins v. Hudson Coal Co., 54 F. Supp. 953 (Pa., I944), aff'd I5 T. 2d 3rI, cert. den. 327 U.S. 777 (I946); Evans v. Hudson Coal Co. I65 F. 2d 970 (x948). See also Van Vloten v. News Syndicate Co., I7 C.C.H. Iab. Cas. 165,520 (D.C. N.Y., I950). Thus the problem of limitation could, it seems, have been determined by such arbitration clauses. It has been suggested that a similar device could be used by unions to preclude harassing suits under Sections 301 and 303 of the Labor Management Relations Act. Gray, Nature and Scope of Arbitration and Arbitration Clauses, New York Univ. First Annual Conference on Labor 197, 2I8 (r948). See also Torff, Taft-Hartley Act and Collective Bargaining: A Management Appraisal, 43 Ill. L. Rev. 323, 343 (1948). 
trability questions. Under the normal four-step grievance procedure it seems reasonable to conclude that the parties have in this instance submitted the question of arbitrability to the final decision of the arbitrator. His decision should stand unless the arbitrator avowedly extends the limitation period.

\section{Partial or Fractional Award}

Under the jurisdictional concept in arbitration, the arbitrator must abide strictly by the provisions of the submission agreement. His award must be responsive to the full scope of that agreement. Because of this, an arbitrator not only is restricted from deciding more than is submitted to him but he is also traditionally enjoined from deciding less than is submitted to him. The principle is that "it is a fundamental requisite of an award that it shall be co-extensive with the submission" and must "embrace all the matters referred to him for decision with a positive adjudication upon each." ${ }^{32}$ If there was no consent to a partial or fractional award, an award on one of two issues is invalid and may be vacated because the arbitrator failed to pass on all matters submitted. ${ }^{43}$ While the proposition is often stated as above, an investigation of the cases reveals that the courts do permit partial awards when the issues and therefore the portions of the award are not interdependent, and the portion of the award sustained may stand alone. An example of this is Moyer v. Van-Dye-Way Corporation ${ }^{44}$ in which the parties submitted disputes regarding three sums allegedly due the employees and the union. The arbitrator found the employees and union were entitled to two of the sums and so awarded. However, on the evidence available he did not feel competent to make an award on the third sum and directed an accounting be had, the company to pay over whatever appeared due on the accounting. The company failed to comply and the union sued in the federal district court for judgment on the award and the amount of the third fund. The district court upheld the award as to the first sum but denied recovery for the second and third sums. The only appeal was by the defendant from judgment for the first sum. The Court of Appeals for the Third Circuit affirmed, and speaking through Judge Goodrich, stated:

42 Application of MacMahon, 63 N.Y. S. $2 d 657$ (1946).

${ }_{33}$ Associated Corset and Brassiere Mfrs. v. Corset and Brassiere Workers, I72 N.Y. Misc. I029, I6 N. Y.S. 2d 736 (I939). The use of the term "fractional award" may be preferable in view of the possible connotation of prejudice in "partial." However, the term "partial award" appears to have some general acceptance.

11 I26 F. 2 d 339 (C.A. 3d, I942). 
It is established, we believe, that an award may be rejected in part and sustained in part. ... It may also be taken as established that if the arbitrator has failed to execute his entire commission and that which he has done does not stand alone but depends in part upon the part unsettled, the award as a whole must fall. . . . On the other hand however, judicial utterance in New York supports the view that when the matters omitted are not necessarily dependent on and connected with the other points a partial award will be sustained. ... The same is true where an award sued on is uncertain in its disposition of part of the case submitted. . . This point of view expresses what is stated to be the now generally prevailing rule of law. ${ }^{45}$

The Boott Mills case is an example of refusing to sustain a partial award where the questions were interdependent. ${ }^{48}$ The parties submitted the two questions of a fair wage and fair work load for loom fixers to arbitration. The board of arbitration decided the wage rate without deciding the work load. The company sought to quash the arbitration proceedings including the award. The Supreme Judicial Court of Massachusetts held the award invalid because of failure to decide both questions submitted when it was "manifest that there questions were interdependent." On this point the court stated:

In so doing the board, acting as arbitrators, did not pursue its commission as to one of the questions submitted for arbitration which had a direct bearing upon the proper determination of the other question as to which an award was made. "That an award which fails to decide all the material questions submitted is invalid, is a principle well established." 47

The results in other cases have followed the same pattern. Where the questions are in fact interdependent, a partial award will not be sustained. ${ }^{48}$ Conversely where the issues are not in fact interdependent, a partial award will be enforced. ${ }^{49}$ Hence, the validity of a partial award appears to turn upon the test of separability.

${ }^{45} \mathrm{Ibid}$., at 34I. The case is also interesting because it involved a New Jersey corporation, a union representing Pennsylvania employees and an award made in New York. The court held the Pennsylvania conflicts of laws rule referred to the law of New York where the award was made and that the award was good under New York law even though the arbitrator did not decide all issues submitted because the partial award was not dependent on matters not decided.

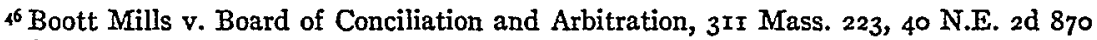
(I942).

47 Tbid., at 226 and $87 x$.

${ }^{8}$ Application of MacMahon, 63 N.Y.S. 2d 657 (1946).

49 In re E. A. Laboratories, Inc., 50 N. Y.S. 2d 222 (1944). See also Publishers Ass'n v.N.Y. Typo. Union, 168 N.Y. Misc. 267, 5 N.Y.S. 2d 847 (r938); Marchant v. Mead Morrison Mfg. Co., 252 N.Y. 284 , 169 N.E. 386 (Ig29); In re Herman, 170 N.Y. Misc. 852, 1o N.Y. S. $2 d 46$ (1938). 


\section{CONCLUSTON}

Judicial review of labor arbitration awards on jurisdictional grounds is necessary and proper. However, it seems necessary strictly to limit this review to the determination of the scope of the submission agreement. If the parties have submitted the questions of arbitrability to the arbitrator, such a submission should be as effective as any other submission. If this procedural protection is given, the award should be final and conclusive on all parties. There should be no retrial of the merits by the court under the guise of a jurisdictional review. To do so will destroy the value of a procedure that has given industry, labor, and the public a service that the courts have not given and probably are not equipped to give. 